\title{
Difference between Cutting Surface of Al Foam and Solid Al Machined by WEDM Technology
}

František Špalek, Marek Sadílek, Robert Čep, Jana Petrů, Jiř́i Kratochvíl, Tomáš Čegan

Faculty of Mechanical Engineering, VŠB - Technical University of Ostrava. 17. listopadu 15/2172, Ostrava. The Czech Republic. E-mail: frantisek.spalek@vsb.cz, marek.sadilek@vsb.cz, jana.petru@vsb.cz, jiri.kratochvil@vsb.cz, tomas.cegan@vsb.cz

The article deals with a comparison of machining of two chemically very similar materials of aluminium alloy, however, with various internal structures by means of non-conventional machining technology of electro-erosive wire cutting (WEDM). The first material used was a right parallelepiped of ALPORAS aluminium foam with porous structure produced by a method of powder metallurgy. As the second material designed to the comparison EN AW 5005 alloy was chosen owing to high aluminium content and therefore a very near chemical composition of the compared material. The samples with circular section of identical height and nominal diameter were produced. On the tested materials sizes of the cutting width were tested, surface structures after machining were observed, dimensional accuracy of cut samples were evaluated and time relationship between cutting of compact and porous structures of aluminium alloy were defined by means of a microscope.

Keywords: aluminium alloy, WEDM, non-conventional technology, measurement

\section{Acknowledgement}

Article has been done in connection with projects Education system for personal resource of development and research in field of modern trend of surface engineering - surface integrity, reg. no. CZ.1.07/2.3.00/20.0037 financed by Structural Founds of Europe Union and from the means of state budget of the Czech Republic and by project Students Grant Competition SP2017/147 and SP2017/149 financed by the Ministry of Education, Youth and Sports and Faculty of Mechanical Engineering VŠB-TUO. This paper was created within the project No. LO1203 „Regional Materials Science and Technology Centre - Feasibility Program" funded by the Ministry of Education, Youth and Sports of Czech Republic.

\section{References}

[1] SADÍLEK, M. (2016). Nekonvenčni metody obráběni I - Elektroerozivní, elektrochemické a chemické obrábění. VŠB TU Ostrava, 104 s., ISBN 978-80-248-3943-1.

[2] SADÍLEK, M. (2016). Nekonvenční metodyobrábění II-Obrábění laserem, plazmou, ultrazvukem, elektronovým, iontovým a vodním paprskem. VŠB - TU Ostrava, 117 s., ISBN 978-80-248-3944-8.

[3] EL-HOFY, H. (2005). Advanced Machining Processes - Non-traditional and Hybrid Machining Processes. The McGraw-Hill Companies, ISBN 0-07-145334-2.

[4] MOURALOVÁ, K., DVOŘÁKOVÁ, J., DVOŘÁK, J., KOVÁŘ, J., KARPÍŠEK, Z., SLIWKOVÁ, P. (2015). Experimental analysis on machinability of aluminium alloy using WEDM technology. MM Science Journal, vol. 4, pp. 722-727. ISSN: 1803- 1269.

[5] MIČIETOVÁ, A., MAŇKOVÁ, I a VELÍŠEK, K. (2007) Top trendy v obrábaní. Žilina: Media/ST, 232 s. ISBN 978-80-968954-7-2.

[6] SOMMER, C. Non-traditional machining handbook. 2nd ed. Houston: Advance Publishing, 391 p. ISBN 978-157537-325-6.

[7] MOURALOVÁ, K., BEDNÁř, J., KOVÁŘ, J., MACH, J. (2016). Evaluation of MRR after WEDM depending on the resulting surface. In: Manufacturing Technology, Vol. 16, No. 2. pp. 396-401. ISSN 1213-2489. Czech Republic.

[8] MIČETOVÁ, A., NESLUŠAN, M., ČILLIKOVÁ, M. (2013). Influence of surface geometry and structure after non-conventional methods of parting on the following milling operations. In: Manufacturing Technology, Vol. 13, No. 2, pp. 199-204. . ISSN 1213-2489. Czech republic.

[9] HO, K. H., NEWMAN, S. T., RAHIMIFARD, S., \& ALLEN, R. D. (2004). State of the art in wire electrical discharge machining (WEDM). In: International Journal of Machine Tools and Manufacture, Vol. 44, pp. 12471259.

[10] ABBAS, N. M., SOLOMON, D. G., \& BAHARI, M. F. (2007). A review on current research trends in electrical discharge machining (EDM). In: International Journal of machine tools and Manufacture, Vol. 47 pp. 1214-1228. 
[11] FABIAN, S., STRAKA, L. (2006). Kvantifikace funkčních závislostí parametru kvality na technologických parametrech při elektroerozivním řezání kovu. In: Strojírenská technologie, Vol. 11, No. 2, pp. 21 - 24.

[12] ČEGAN, T., ZIENTEK, S., NOSKO, M., POHLUDKA, M., HORSÁK, L., ŠPALEK, F. (2016). Characterisation of structural and compressive properties of aluminium foam alporas. In: METAL 2016:25th International Conference on Metallurgy and Materials. Hotel Voronez I, Brno, Czech Republic, Ostrava: TANGER Ltd., pp. 1362-1367, ISBN 978-80-87294-67-3.

[13] ŠPALEK, F., PETRŮ, J., ZLÁMAL, T., MRKVICA, I., ČEP, R., KRATOCHVÍL, J. (2016) Electro-Erosive Wire Cutting of Aluminum Foam. In: Manufacturing Technology, Vol. 16, No. 2, pp. 449-453. . ISSN 1213-2489. Czech republic.

\section{Paper number: M2017156}

Copyright $($ ) 2017. Published by Manufacturing Technology. All rights reserved. 